kvinner gitt feministiske bidrag til tolkningen av melodramaet. Jeg kan nevne E. Ann Kaplans Motherhood and Representation: The Mother in Popular Culture and Melodrama, Christine Gledhills Home is where the Heart is. Studies in Melodrama and the Woman's Film og den før nevnte Rita Felskis bok The Gender of Modernity. Det fins også en ganske ny studie av melodramaet i nordisk litteratur, nemlig Maria Karlssons bok Känslans röst om Selma Lagerlöfs romaner fra 2002.

Det er selvsagt ikke mulig å ta hensyn til alle relevante bidrag i en så omfattende og litteraturhistorisk orientert avhandling som Anne Birgitte Richard har skrevet, men ofte synes jeg at de detaljerte og lange tekstparafrasene ikke får tilstrekkelig kontekstualisering. Hvorfor skriver kvinnene melodrama og ikke modernisme? Hva betyr det for deres status i den litterære offentligheten $\mathrm{og}$ for verdien av deres kunst? Når tekstene ikke sjelden får en teoretisk belysning som mangler det spesifikt kjønnede perspektiv, så framstår det desto mer som et savn. Med impulser fra disse feministiske lesningene av det litterære og filmiske melodrama, tror jeg at boka på en tydeligere måte kunne ha fått fram hvordan og med hvilken effekt kjønnet knytter seg til og produserer estetiske normer og hierarkier.
Jon Helt Haarder

\section{Mellemkød, blandt andet}

Per Stounbjerg: Uro og urenhed. Studier $i$ Strindbergs selvbiografiske prosa, Århus 2005 (Aarhus Universitetsforlag).

Har man været væk fra Strindberg lidt, glemmer man let, hvor ekstrem han er som selvbiograf. Kæfter op om eksens monsteragtige mangel på moral og abeagtigt intellektuelle underlegenhed, og siger så: »Ja, jeg holder mig for god til overhovedet at nævne, at hendes mellemkød revnede efter den første fødsel, og værre blev det kun efter de næste tre, adr mand!« Nu har jeg pendlet lidt rundt på nettet, der egner sig fortrinligt til at hævne sig på ekser ved hjælp af offentliggjorte slibrigheder, og meget interessant kød har jeg set, men ikke lige bristet mellemkød. August, du styrer stadig.

Per Stounbjergs disputats om August Strindbergs selvbiografiske prosaforfatterskab var ved at få samme status som Per Højholts Auricula. Man vidste den var på vej, men vejen var lang. I et selvbiografisk forord oplyser Stounbjerg, at afhandlingen i det væsentlige var færdig helt tilbage i 1993, men så gik der lige ti år med forskellige ledelsesposter. Offentliggjorte artikler har undervejs antydet, at den var værd at vente på - og her sidder anmelderen så med „Uro og urenhed. Studier i Strindbergs selvbiografiske prosa", der blev forsvaret den 27. maj 2005. 
De yderste rammer om Stounbjergs arbejde er litteraturhistoriske. Han vil vise, at det selvbiografiske prosaforfatterskab er på niveau med den dramatik, der indskrev Strindberg i verdenslitteraturen. Delvis som argument for denne påstand kortlægger Stounbjerg et mangefacetteret spil mellem realisme og modernisme i en særlig strindbergsk selvbiografisk æstetik, der på den ene side kræver nye bestemmelser af de slidte termer, og som på den anden viser forfatterskabet som en meget egensindig version af en gængs litteraturhistoriografisk konstruktion: Modernismens formelle eksperimenter som privilegeret fortolkning af modernitetens tab af faste referencerammer.

For at få form på et arbejde af denne type, må Stounbjerg foretage to operationer. Han skal for det første have afgrænset, hvad han mener med "Strindbergs selvbiografiske prosa». For det andet skal han have ryddet op i både selvbiografiens genrespørgsmål og de velkendte teoretiske og metodiske diskussioner om selvbiografisk reference. Hvad angår det første, følger han den sene Strindbergs oplistning af Tjänestekvinnans son, Jäsningstiden, I röda rummet, Författeren, Han och hon, Le Plaidoyer d'un fou, Inferno, Legender, „Karantänemesterens andra berättelse« og Ensam som et sammenhængende selvbiografisk værk med løbende tilblivelse fra 1886 til 1903. Han ser bort fra, at Strindberg også ønskede Ockulta Dagboken og brevene udgivet som en del af denne monstrøse selvbiografi. Argumenterne herfor er dels pragmatiske (brevene fylder 22 bind), og dels at fokus er på »tekster, der eksplicit er tilrettelagt med henblik på offentliggørelse« (25). Det sidste er i forhold til brevene et måske lidt tvivlsomt argument (Han och hon består f.eks. også af autentiske breve), men så er der jo pragmatikken. I forhold til en hel række andre tekster, der kunne have været inddraget, støtter Stounbjerg sig ud over Strindbergs egne udtalelser på både receptions- og udgivelseshistorien. Alt i alt et velbegrundet tekstudvalg, også fordi Stounbjergs pointer ikke står og falder med, om man nu kunne argumentere for at denne eller hin tekst burde have været med.

En lille anke er, at han primært holder sig til "Karantänemesterens andra berättelse", der er en klodset sminket version af den meget direkte roman om tiden i Berlin og ægteskabet med Frida Uhl, som Strindberg ikke turde udgive under titlen Klostret. Forskellen på de to tekster er udover den biografiske defacement af de tidligere drikkebrødres og damebekendtskabers kontrafejer en lang indledning, der dels er langt det bedste ved den lidt kedelige tekst, dels faktisk på et afgørende punkt støtter Stounbjerg: Bevægelsen fra en eksistentielt, politisk og religiøst til en æstetisk begrundet omgang á la montage med det (selv)biografiske stof er programmatisk tydelig i Klostrets første kapitel. At dette skal nævnes i en fodnote (uden inddragelse af Frits Pauls behandling af spørgsmålet) peger på, at romanen snarere end novellen skulle have været i fokus.

Hvad angår tekstudgaverne, der i de fleste tilfælde giver permanent editionsfilologisk migræne, hvis man vil have arketekstuel grund under fødderne, da bruger Stounbjerg primært de først skrevne versioner - hvad man især bemærker i forhold til Inferno, En dåres försvarstal og Legender, der læses 
på fransk (den sidstnævnte er dog kun delvis på fransk) - men med inddragelse af andre udgaver. Også her ser man viljen til at læse forfatterskabet $\mathrm{i}$ dets internationale, snarere end dets snævrere nordiske sammenhæng.

Hvad er så en selvbiografi, og hvordan skal den læses? Ja, Stounbjerg siger i begyndelsen sådan: "Tekster er ikke selvbiografier, men de kan loeses som sådanne« (25). Men han siger og gør noget andet i resten af afhandlingen. Heldigvis, for påstanden er genreteoretisk uholdbar og ville omsat i praksis have fjerne fundamentet under projektet. Nok underskriver han ikke uden videre Phillipe Leujeunes berettiget berømte forsøg på en endegyldig genredefinition - den selvbiografiske pagt baseret på bestemte tekstuelle karakteristika - men hans argumenter for, hvornår bestemte tekster så skal »loeses som sådanne«, er i sagens natur blandt andet baseret på bestemte tekstuelle karakteristika; det være sig brug af navne, en fokusering på protagonistens indre udvikling eller strukturel lighed mellem hændelser og forløb i teksten og Strindbergs i offentligheden kendte privatliv. Sådanne træk omtaler Stounbjerg, helt i modstrid med påstanden om, at genrer ikke findes, som historisk virksomme skrivekonventioner. I centrum af undersøgelserne står da, hvordan Strindberg bruger og bruges af selvbiografien i det sene 1800-tal.

Det 'blandt andet', jeg brugte ovenfor, er formentlig de vigtigste ord i nærværende anmeldelse (måske lige bortset fra 'mellemkød'), for de udpeger den eklekticisme, der er Stounbjergs metode. Metoden er med en pudsig og genkommende formulering både »tekstteoretisk oplyst «, traditionel biografisk og pragmatisk, for ikke at sige performativt orienteret - svarende til at selvbiografier på den ene side er en slags tekster med en historie og en retorik, med en referentialitet og en eksistentiel tyngde, som Stounbjerg fuldstændig korrekt nægter at reducere til tekst. På den anden side er det at skrive og udgive selvbiografier handlinger $\mathrm{i}$ et offentligt rum. Hvad angår det sidste, bruger Stounbjerg dog ikke 90ernes 'performative vending', men sin egen gode dømmekraft og f.eks. Elisabeth Bruss' begreb om Autobiographical Acts (1976), der mere snusfornuftigt, end vi normalt ser det i disse post-butlerske tider, trækker på Austin og Searle.

Især i forhold til dette handlingsaspekt er det tydeligt, at disputatsen har ligget nogen tid inden udgivelsen. Jeg synes, Eva Hættner Aurelius' fundering af selvbiografien i den juridiske forsvarstale (Inför Lagen, 1996) havde fortjent at blive brugt til mere end en fodnote i en analyse af en selvbiografi, der direkte hedder Plaidoyer. Det havde muligvis også bragt det underbelyste spørgsmål om køn i spil. Hættners undertitel er Kvinnliga svenska självbiografier från Agneta Horn till Frederika Bremer. Afhandlingen kunne ligeledes have hentet inspiration i performativitetsteori - og måske samtidig have sat de kropsqueerkompostfeministisk rablende kunsthistorikere og dramateoretikere på plads: Litteraturen var der først, med mellemkød og det hele. Disse indvendinger til trods er Stounbjergs arbejde banebrydende i forhold til de biografiske problemstillinger. Man burde tvinge både biografister af Aage Henriksen-skolen og tekstualister af formalistisk, kognitivistisk eller post- 
strukturalistisk observans til at læse første del af afhandlingen.

Uro og urenhed hedder afhandlingen altså, og dermed er der tydeligt peget på de træk i Strindbergs selvbiografiske æstetik, som Stounbjerg trækker frem: genrehybriditet, diskursutroskab, mistro til færdige synspunkter og udviklingsbegreber, ja til fortællingen selv som færdig. Gennemgående er således, hvad Stounbjerg kalder reversibilitet: at enhver hårdt tilkæmpet løsning af 'mitt livs ekvation' til enhver tid kan kaldes tilbage - og bliver det både i den enkelte tekst og i hele rækken af tekster. Metaforen 'svingdør' bliver hyppigt brugt. Stounbjergs eget tekstteoretisk oplyste stade fornægter sig ikke i hans læsepraksis, hvor al denne turbulens primært ses som formationer i teksterne. Turbulensen angår imidlertid også netop forholdet mellem tekst og alt det udenom.

Ingen af teksterne falder til ro i forhold til selvbiografien som genre. I Tjänestekvinnans son (skrevet 1886) overlejrer forskellige ikke-personlige diskurser (kulturkritik, religion, forskellige typer videnskab) selvbiografiens angivelige kerne af levet liv, ligesom dannelse og determinisme $\mathrm{i}$ skildringen af hovedpersonens udvikling river øjnene ud på hinanden. Den biografiske og selvbiografiske reference drives omvendt til absurde dokumentaristiske ekstremer i Le Plaidoyer d'un fou (skrevet 1887-1888) med en paradoksal og stærkt foruroligende form for virkelighedstab til følge. På langs af forfatterskabet ser Stounbjerg en stadig stærkere tendens til, at den allerede i sig selv modsætningsfulde naturalisme i de tidlige selvbiografiske tekster gradvist kombineres med og afløses af en vildt- voksende allegorisering af det personlige materiale, der kulminerer med Inferno (skrevet 1897) for så at klinge ud i Ensams (1903) postulerede resignation. Selvbiografien bliver til allegoriske momenter uden stabil referenceramme. Noget Stounbjerg resolut sætter på en epokaltypisk epistemologisk formel: Strindbergs selvbiografiske æstetik er udtryk for en modernistisk fortolkning af en modernitetens krise i repræsentationen - kun for ved disputatsens tæppefald at kunne konstatere, at den tilsyneladende resigneret-afklarede drømmespilsmodernisme af den ældre Strindberg forlades til fordel for endnu mere frenetiske udladninger $i$ et realistisk-genkendeligt prosaregister hinsides de almindelige genreopdelinger.

I forhold til Strindberg-forskningen vedkender Stounbjerg sig arv og gæld fra især Michael Robinsons banebrydende Strindberg and Autobiography (1986), mens f.eks. Ulf Olssons arbejder fra halvfemserne uden at være overset ikke har spillet den samme rolle. De meget omfattende ide- og lærdomshistoriske undersøgelser, som forfatterskabet har været genstand for, er forudsætninger for bestemmelser af spillet mellem selvbiografiens traditionelle indadvendthed og så Strindbergs vilje til at skrive sig og sit ind $i$ alle mulige og især umulige diskurser. Hvad angår de store biografer, specielt Brandell og Lagercrantz, ligger Stounbjerg også her i mellemkødet. Uenig med den første $\mathrm{i}$ hans traditionelle manden-bag-værket-fokusering, uenig med den sidste i hans hypostasering af den skabende Strindberg som en noget nær almægtig master of puppets i skrivningen af sit eget liv. Enig med begge i den 
biografiske references irreducible relevans.

Dermed nærmer vi os spørgsmålet om Strindbergs psykiske konstitution, som Stounbjerg nok interesserer sig for, men kun som dette kommer til syne i de behandlede tekster. I et vigtigt afsnit af afhandlingen behandler han "En melankolsk konstellation" i hele det behandlede tekstkorpus. Inspirationen kommer fra fransk psykoanalyse, især Kristeva. Pointen er, at de voldsomt modsætningsfyldte karakteristika, Stounbjerg samler under begreberne uro og urenhed, udviser et genkommende mønster, nemlig en overdetermineret tabsfiksering, der kommer til syne $i$ en altgennemtrængende blanding af afhængighed af og rædsel for de andre og det andet, det være sig venner, koner, genrekonventioner eller litterær inspiration. Dermed har Stounbjerg ikke underskrevet psykologernes diagnoser af den empiriske Strindberg. Han har snarere peget på en slags inderside af den krise i repræsentativiteten, han ser som de behandlede teksters gennemgående tema. Strindberg selvbiografiske tekster viser, at det moderne subjekt er permeabelt og ustabilt og dermed i sidste ende nærmest ufremstilleligt som andet end skiftende identifikationer. Modsat senere attituderelativistiske, konstruktivistiske eller performative teorier om identitet ser Strindberg dette i dystopisk snarere end utopisk belysning.

Det er lidt uafklaret, hvorvidt Stounbjerg selv i sidste ende ser realisme og modernisme som sideordnede eller successive reaktioner på moderniteten - han giver udtryk for begge holdninger. For denne anmelder er der ikke tvivl om, at en af disputatsens fortjene- ster netop er fremstillingen af uro og urenheder i forholdet mellem to sideordnede og nogenlunde jævnaldrende svar på og interventioner i det moderne. Den generelt litteraturhistoriografiske interesse i Strindbergs selvbiografiske prosaforfatterskab består blandt andet i dets problematisering af modernicismen, dvs. totaliseringen af den modernistiske æstetik til selvfed teleologi og eviggyldige afpersonaliseringsdogmer.

Trods stedvise reservationer skal Stounbjergs disputats have mine varmeste anbefalinger. Et fascinerende aspekt af et fascinerende forfatterskab æltet igennem med format, overskud og belæsthed. Der er en smittende idérigdom i analyserne, som dårligt kommer til udtryk i anmeldelsens referat. Hertil kommer, at Stounbjerg nok bruger, hvad jeg ville kalde Århus-litterat-lingo - skrift, felt, repræsentation (og torso for en ufuldendt tekst ikke at forglemme) - men til gengæld skriver forbilledlig præcist i behageligt korte sætninger, der stort set på hver side rammer prægnante formuleringer, man straks understreger.

\section{Anne Borup}

Dan Ringgaard: Nordbrandt, Århus 2005 (Aarhus Universitetsforlag).

Der er nogle forfatterskaber man med stor lyst rålæser i lange stræk, mens andre helst skal indtages i mindre bidder. Med Nordbrandts poesi er det lidt som med god konfekt: altid fristende og lækker, men bedst i afmålte doser. Sådan er det i hvert fald for denne anmelder. Det var derfor med et vist forbehold jeg gik i gang med Århus-litteraten Dan Ringgaards bog om Henrik 